\title{
Growth variability of European beech (Fagus sylvatica L.) natural forests: Dendroclimatic study from Krkonoše National Park
}

\author{
Václav Šimůnek ${ }^{1}$,Zdeněk Vacek ${ }^{1}$ *, Stanislav Vacek ${ }^{1}$, Ivo Králiček ${ }^{2}$, Karel Vančura $^{1}$ \\ ${ }^{1}$ Czech University of Life Sciences Prague, Faculty of Forestry and Wood Sciences, Kamýcká 129, \\ CZ - 16521 Prague 6 - Suchdol, Czech Republic \\ ${ }^{2}$ University of Hradec Králové, Faculty of Science, Rokitanského 62, CZ-500 03 Hradec Králové, Czech Republic
}

\begin{abstract}
Long-term temporal development of beech stands in relation to climatic conditions is well documented by dendrochronological analyses. The study aims to identify and describe growth factors affecting natural European beech stands (Fagus sylvatica L.) on permanent research plots in the eastern Krkonoše Mountains, the Czech Republic. The paper focus on radial growth dynamics, frequency and cyclicity, and the effect of climatic factors on diameter increment of beech stands since 1850 . The growth development of beech stands was significantly affected by air pollution load in 1977-1989, and increasingly frequent climate extremes in recent years (since 2010). Periodic increment events recurred in approximately 10-18 years' periods. Stands on research plots responded differently to climatic factors, the main limiting factor being low temperatures during the growing season, frost damages and extreme droughts. The positive influence of temperatures on beech increments was recorded in winter, early spring, and especially in July and August of the current year. Conversely, precipitation in the previous year had higher impact on radial increment, with prevailing negative correlation. The plots were negatively affected by the decrease in sum of precipitation in February and March, but it was the temperature that influenced the beech increment most significantly. Dendrochronological analysis of close-to-nature beech stands provides valuable information on radial forest growth in response to changing climatic conditions.
\end{abstract}

Key words: dendrochronology; tree-ring data; cyclical dynamics; temperature; precipitation; Central Europe

Editor: Bohdan Konôpka

\section{Introduction}

In terms of ongoing global climate change, European beech stands (Fagus sylvatica L.) show greater stability and resistance to water scarcity than Norway spruce stands (Picea abies [L.] Karst.) - (Dittmar et al. 2003; Zang et al. 2011, 2014; Hartl-Meier et al. 2018). Climate change has long been forcing forestry management to change its approach to tree species composition in favour of deciduous tree species. Confirming the trend, the Czech Republic has witnessed an increasing percentage of European beech (1\% increase since 2010) (Ministry of Agriculture 2017). Supposedly, the numbers will increase continually. As a result, European beech will partially substitute languishing stands of Norway spruce (Lindner et al. 2010; Holuša et al. 2018). Some studies, however, point out European beech sensitive response to long-lasting drought (Jump et al. 2006; Geßler et al. 2007; Granier et al. 2007; Cavin \& Jump 2017). In comparison to spruce stands, beech stands show greater success of natural regeneration (occurrence, density, growth) and adaptability to air pollution (Králíček et al. 2017; Slanař et al. 2017). The higher resilience and plasticity of the beech compared to spruce is caused by the annual replacement of the assimilation apparatus. However, during the long-term impact of pollution load the forest damage increased through the soil due to increased acidification, disruption of the sorption complex and decrease of mycorrhizal roots (Ling et al. 1993; Power \& Ashmore 1996). In response to climate change, beech stands increase the frequency of seed years (Övergaard 2010). Growth processes of the tree species are also affected, its mortality increasing with increasing drought at lower altitudes, yet with the effect of prolongation of its lifetime cycle (Filippo et al. 2012).

As soon as the beginning of the 20th century, the first national parks began to emerge in Europe, together with increasing preferences for ecological approach to forests, which led to greater interest in close-to-nature forestry 
(Christensen et al. 2005). National parks, including our area of interest in the Krkonoše Mountains, took over the beech stands with their noteworthy history. From the 17 th to the 19 th century the beech stands were used as forest pastures and source of cattle feed - beech nuts (Nožička 1961; Lokvenc 1978). For many centuries, beech stands were also used for fuel wood and production of charcoal (Peters 1997). In recent decades, the health status and development of forest stands were damaged by synergic effects of air pollution load (acidification, ozone effect) and climate stress (extreme fluctuations, frosts, droughts, wind storms) (Bytnerowicz et al. 2007; Paoletti et al. 2010; Vacek et al. 2013, 2015a).

Together with industrial development and increasing air pollution after World War II, the first macroscopically visible large-scale damage to forest stands in the Czech Republic occurred (Materna 1989). Consequently, the most significant air pollution loads caused by high concentrations of $\mathrm{SO}_{2}$ were recorded in the Krkonoše Mountains in the 1970s-1990s (Bridgman 2002; Matějka et al. 2010; Vacek et al. 2010; Král et al 2015; Vacek et al. 2017). Since the 1990s, $\mathrm{NO}_{\mathrm{X}}$ and $\mathrm{O}_{3}$ air pollution have also been perceived as a problem (Hůnová \& Schreiberová 2012; Vacek et al. 2015a). Mankind has influenced forests throughout history, and on this basis it was found that $85 \%$ of beech stands developed in regeneration cycles of 15-25 years, with high-level regeneration in subdominant trees (Schütz 2001).

The Krkonoše Mountains stands were affected not only by air pollution loads but also by climatic factors such as ground frosts in 1977, wind disturbances in 2007 and 2008, or in increasingly frequent extreme droughts in recent years (Trnka et al. 2015; Bošel'a et al. 2016; Brázdil et al. 2017, 2018). Damaged by air pollution, forests were consequently infested with beech scale (Crypotococcus fagi /Baer./ Dougl.), followed by gummosis and more than often also by bark canker (Vacek 1988). Canker and necroses in beeches are most frequently induced by Nectria, Ophiostoma, Phomopsis and Verticillium pathogens, or some species of Phytophtora, fungi causing vast damage throughout Europe (Motta et al. 2003; Cicák et al. 2006). Among other pests in the Czech Republic we can name beech-leaf gall midge (Mikiola fagi Htg.), Bucculatrix ulmella Zeller and Ectoedemia liebwerdella Zimm. (Urban 2000; Mihál et al. 2014). All these abiotic and biotic factors affect the growth conditions of European beech stands on the research plot. Last studies bringing results of long-term research of natural beech stands in the eastern Krkonoše Mts. were published in 2010 and 2015, focusing on the European beech stand structure and the effects of air pollution (Špulák \& Souček 2010; Vacek et al. 2015b), but no research on dendrochronological development of these unique forest stands has been published yet.

This study explores the potential of the cyclical dynamics of European beech in stands left to spontaneous development in conditions of the climate change and uses a dendrochronological analysis that combines the evaluation of frequency dynamics of the lower and higher "bandpass filtering" of dendrochronological series (Bunn \& Mikko 2018a, 2018b). The study also evaluates the effect of monthly temperatures and precipitation on radial growth to differentiate responses to climate during a particular season (Biondi \& Waikul 2004). Particular attention is given to clarification of the influence of climate change on natural beech stands in the eastern part of the Krkonoše Mountains National Park, which was left to spontaneous development in 1963.

\section{Material and methods}

\subsection{Study area}

The studied area of Boberská strán̆ (Rýchory Hills) is situated in the east of the Krkonoše Mountains National Park near the town of Žacléŕ, close to Poland frontier. Studied three permanent research plots (PRP 30, 31, 32) with similar growth conditions are composed by dominant European beech (99.8-100.0\%) and admixed sycamore maple (Acer pseudoplatanus L.; 0.0-0.2\%). Research areas are in the first zone of protection of the Krkonoše National Park at an altitude of 740-790 ma.s.l. on a northeast facing slope. The predominant soil type is the Cambisol with meta-diabase subsoil. The climate at the site is characterized by temperatures oscillating around $5.2^{\circ} \mathrm{C}$ with an annual total precipitation of 870 $\mathrm{mm}$. The growing season lasts about 120 days with an average temperature of $11.9^{\circ} \mathrm{C}$ and a total precipitation of $640 \mathrm{~mm}$. In Köppen's classification, this is a damp continental climate with warm summers (Dfb) - (Tolazs 2007). Phytosociology defines the area as Fagion sylvaticae Luquet 1926, Eu-Fagenion Oberdorfer 1957 suballiance and Dentario enneaphylli-Fagetum Oberdorfer ex W. et A. Matuszkiewicz 1960 plant association. In 1963, natural beech stands on the PRPs were left to spontaneous development.

The studied PRPs of $50 \times 50 \mathrm{~m}$ (area of $0.25 \mathrm{ha}$ ) were established by Forestry and Game Management Research Institute, Forest Research Station at Opočno in 1980 to monitor long-term factors affecting the forest environment (Vacek 1988). Several measurements by technology Field-Map (Institute of Forest Ecosystem Research - Monitoring and Mapping Solutions Ltd.; IFER 2017) were carried out on these PRPs, studies of which were published (Vacek et al. 2010; Vacek et al. 2015b). This technology was used for repeated measurements of the positions of tree layer, dead wood and natural regeneration, tree heights, heights of the live crown base and crown projection areas together with the diameters at breast height (DBH). Fig. 1 illustrates the localization of natural beech forest stands on PRPs and Table 1 shows the basic site and stand characteristics of PRPs. 


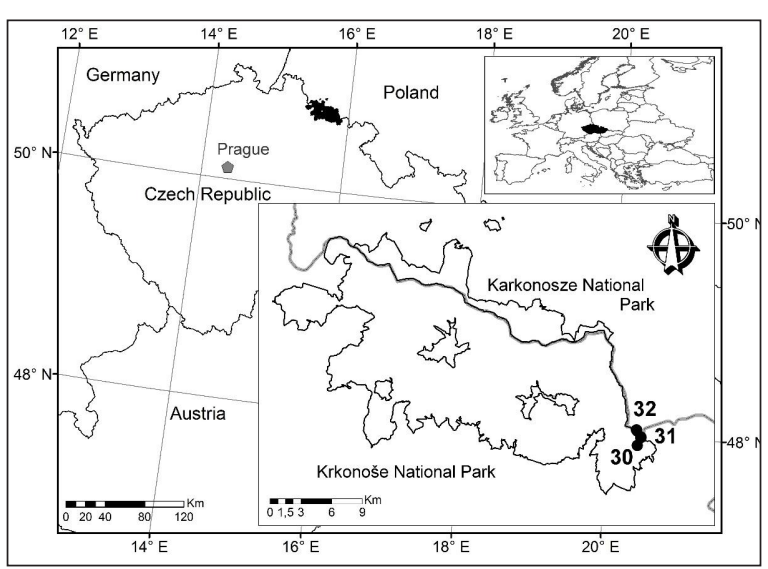

Fig. 1. Location of European beech forest stands on permanent research plots 30, 31 and 32 in the Krkonoše Mountains.

\subsection{Data collection}

For dendrochronological analysis, increment cores were taken from the European beech using the Pressler auger, perpendicularly to the stem axis, in the down-the-slope direction. Trees were randomly selected using the RNG selection (MS Excel); a total of 72 cores (24 per PRP) were taken from trees with $\mathrm{DBH}>250 \mathrm{~mm}$. The analysis required 67 samples: 23 from PRP 30, 21 from PRP 31, and 23 from PRP 32. Cores were measured by an Olympus microscope on a LINTAB measurement table (RINNTECH). The samples were measured from the bark to the heartwood, perpendicularly to the centre of the stem so that each ring was measured perpendicularly to the axis of the stem with an accuracy to hundredths of millimetres. Subsequently, the increment cores were crossdated in CDendro program (Cybis Dendrochronology), with the $\mathrm{CC}>25$.

Climate data (monthly air temperatures and sum of precipitation) were taken from the nearest meteorological station of Pec pod Sněžkou (Czech Hydrometeorological Institute, Prague), $11 \mathrm{~km}$ from research areas at an altitude of 816 m a.s.l. (5041'30.480“ N , 1543‘43.320“E). The range of climate data surveyed was set to the 19762017 period. Data on average annual temperatures, growing season temperatures, temperatures out of the growing season, temperatures in particular months and annual sum of precipitation, sum of precipitation in the growing season, precipitation out of the growing season, precipitation in particular months in 1976-2017 were used to describe the development of temperature and precipitation conditions. The meteorological data source was provided by operator Czech Hydrometeorological Institute. Climatic data was archived by the National Climatic Data Center.

\subsection{Data analysis}

Dendrochronological analysis data were processed in the R (R Core Team 2018) program, using negative exponential detrending to remove the age trend of analysed increment cores with an inserted spline of $1 / 3$ sample age. Consequently, the values were averaged by the chron function (Bunn \& Mikko 2018b). To generate information for each chronological curve signal, dplR-packages for R and signal were used. A graph of single high-pass filter spectrum signal was created in period ranges of 1 to 20 years. Splines from 4, 8, 16, 32, 64 to 128 years were inserted to the average data curve to show significant events (Bunn \& Mikko 2018a; Team R Core 2018). DendroClim 2002 (DendroLab) was used for the analysis of dendrochronological curves with monthly climatic conditions, utilizing the response and correlation function in the months from May to September (Biondi \& Waikul 2004).

Data from the evaluation of diameter increment of beech in relation to climate factors were statistically processed by the Statistica 12 program (Statsoft, Tulsa). To determine the combined effect of average annual temperature and annual sum of precipitation on radial growth of beech, the regression quadratic model was used. The principal component analysis (PCA) was run in CANOCO 5 program (Lepš \& Šmilauer) to assess the relation between the radial growth of beech forest stands, sum of precipitation and average temperatures all the year round, in the growing season (from April to September), out of the growing season (from October of the previous year to March of the current year), in June to July and in January to March of the current and previous year. Prior to the analysis the data were logarithmized and standardized. The results of multivariate PCA were visualized in an ordination diagram.

Table 1. Overview of basic site and stand characteristics of permanent research plots (according to the Forest Management Plan).

\begin{tabular}{|c|c|c|c|c|c|c|c|c|c|c|}
\hline PRP & $\begin{array}{c}\text { GPS } \\
\text { coordinates } \\
\end{array}$ & $\begin{array}{c}\text { Altitude } \\
{[\mathrm{m}]}\end{array}$ & Exposure & $\begin{array}{c}\text { Slope } \\
{\left[{ }^{\circ}\right]} \\
\end{array}$ & Tree species & $\begin{array}{c}\text { Age of tree layers } \\
\text { [years] }\end{array}$ & $\begin{array}{l}\text { Height } \\
{[\mathrm{m}]}\end{array}$ & $\begin{array}{l}\mathrm{DBH} \\
{[\mathrm{cm}]}\end{array}$ & $\begin{array}{l}\text { Volume } \\
{\left[\mathrm{m}^{3} \mathrm{ha}^{-1}\right]}\end{array}$ & Forest type* \\
\hline \multirow{2}{*}{30} & $50^{\circ} 39^{\prime} 52^{\prime \prime} \mathrm{N}$ & \multirow{2}{*}{790} & \multirow{2}{*}{$\mathrm{NE}$} & \multirow{3}{*}{24} & beech & \multirow{3}{*}{$182 / 22$} & 31 & 49 & 420 & \multirow{2}{*}{$6 \mathrm{D}$} \\
\hline & $15^{\circ} 53^{\prime} 01^{\prime \prime} \mathrm{E}$ & & & & sycamore & & 28 & 40 & 38 & \\
\hline \multirow{3}{*}{31} & $50^{\circ} 40^{\prime} 04^{\prime \prime} \mathrm{N}$ & \multirow{3}{*}{740} & \multirow{3}{*}{$\mathrm{NE}$} & & beech & & 29 & 43 & 398 & \multirow{3}{*}{$6 \mathrm{~B}$} \\
\hline & 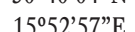 & & & \multirow[t]{2}{*}{23} & sycamore & \multirow[t]{2}{*}{$165 / 23$} & 27 & 39 & 40 & \\
\hline & & & & & spruce & & 31 & 40 & 20 & \\
\hline \multirow{2}{*}{32} & $50^{\circ} 40^{\prime} 13^{\prime \prime} \mathrm{N}$ & \multirow{2}{*}{760} & \multirow{2}{*}{$\mathrm{NE}$} & \multirow{2}{*}{35} & beech & \multirow{2}{*}{$149 / 71 / 24$} & 26 & 41 & 313 & \multirow{2}{*}{$5 B$} \\
\hline & $15^{\circ} 52^{\prime} 48^{\prime \prime E}$ & & & & sycamore & & 26 & 35 & 34 & \\
\hline
\end{tabular}

Notes: *Forest site type classification:6D - Piceeto-Fagetum acerosum diluvium (Enriched-colluvial spruce-beech), 6B - Piceeto-Fagetum eutrophicum (Nutrient-rich spruce-beech), 5B - AbietoFagetum eutrophicum (Nutrient-rich fir-beech) - (Viewegh et al. 2003). 


\section{Results}

\subsection{Dynamics and frequency of radial growth}

Detrended radial growth data series (Fig. 2) show that each stand on the studied PRPs developed differently. On PRP 30, no substantial drops in production were detected. This finding is also related to the fact that only five climatically significant years (12) were documented on the PRP until 1973. PRP 31, though, witnessed the highest number of climatically significant years (13) in terms of radial growth, and the increment varied significantly throughout the years. PRP 32 showed the most substantial cyclicity of radial growth and revealed five climatically significant years.

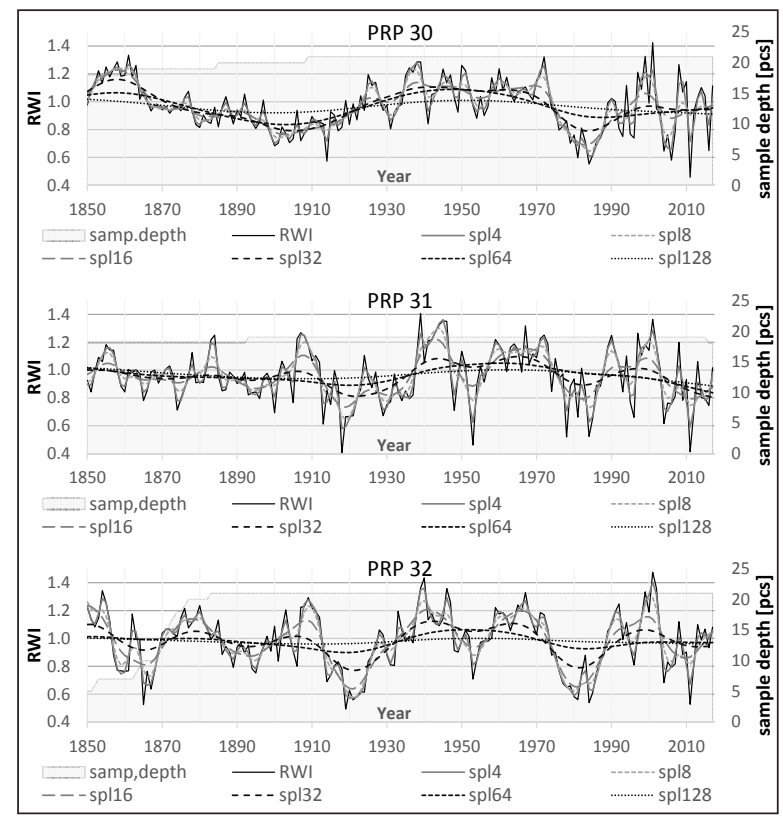

Fig. 2. Standardized ring-width chronologies of European beech on permanent research plots 30,31 and 32 with added splines and sample depth (RWI - ring-width index, spl4 spline 4 years, spl 8 - spline 8 years, spl16 - spline 16 years, spl32 - spline 32 years, spl64 - spline 64 years, spl128 spline 128 years).
On Boberská stráň, beech stands generally show great plasticity of radial growth (Fig. 2). The analysis of climatically significant years since the mid-19th century for all PRPs shows major significances as late as in 2011, 2016 and 2017. During the $3^{\text {th }}$ to $8^{\text {th }}$ May in 2011 the temperature was $-8^{\circ} \mathrm{C}$, which these extreme late spring frosts damaged the fresh budding leaves and negatively affected whole growth of European beech in season 2011. The year of 2016 was specific for frost damage of the assimilation apparatus, serious infestation with beech-leaf gall midge and a significantly low precipitation of about $1000 \mathrm{~mm}$ (300 mm below an average).

Forest stands on each PRP developed differently, while the longest, 17-year periodic growth cycle of beech occurred in PRP 31; the following cycles repeated every 2, 5, 6 and 7 years (Fig. 3). In PRP 30, the cycles repeated mostly in periods from 10 to 16 years. PRP 32 witnesses small cycles from 2 years and significant periods from 6-7, 10 and 18. Overall, in all PRPs, periods from 10 to 18 years prevail (Fig. 3 ).

\subsection{Effects of temperature and precipitation on radial growth}

In term of monthly air temperatures in relation to the average annual radial growth of beech, the growth responds positively in May of the previous year, where significant $(\mathrm{P}<0.05)$ values $(\mathrm{r}=0.30-0.37)$ were found for PRP 30 and 31 (Fig. 4). Other significant months are January and February of the current year, when PRP 31 and 32 are significant $(r=0.23-0.42)$ and PRP $30(r=$ 0.24 ) shifts the relation to February and March (i.e. by one month). In August of the current year, all stands on the PRPs $(r=0.28-0.44)$ responded significantly, with a longer response in PRP 32 - from July to August. In total, PRP 32 responds most significantly, followed by PRP 30, where a minor trend is apparent during growing periods, depending on the linear curve. All PRP stands show a rising positive trend of temperature effects in individual months (Fig. 4).

The effect of monthly sum of precipitation on the PRPs stands varies during vegetation periods (Fig. 5). The first significant month is August of the previous year,

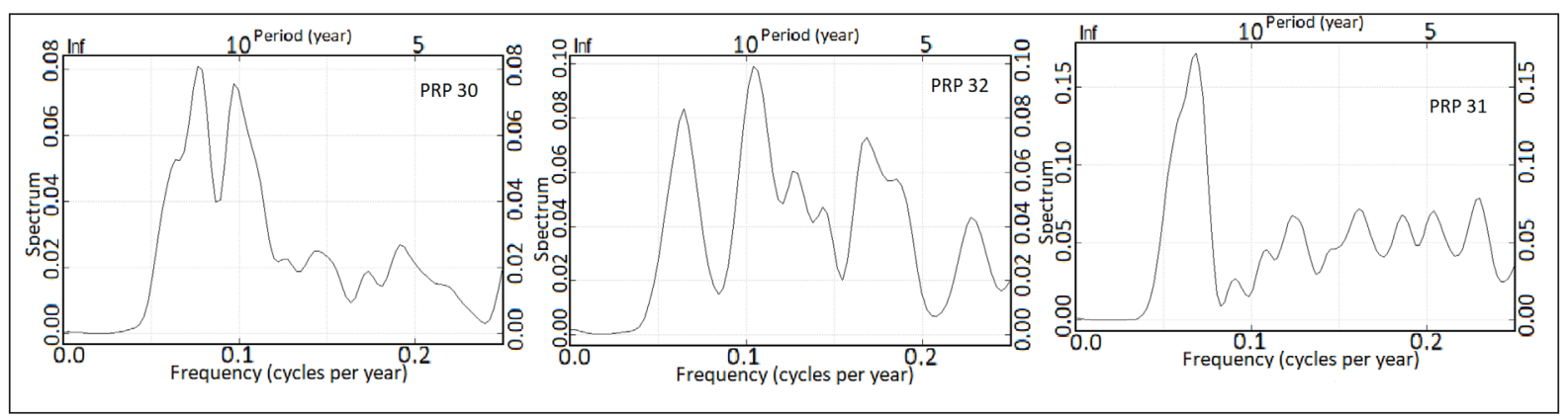

Fig. 3. Single spectral analysis of the indexed ring-width chronology for permanent research plot 30, 31 and 32, with middle pass filtering from 1 to 20 years cycles. 


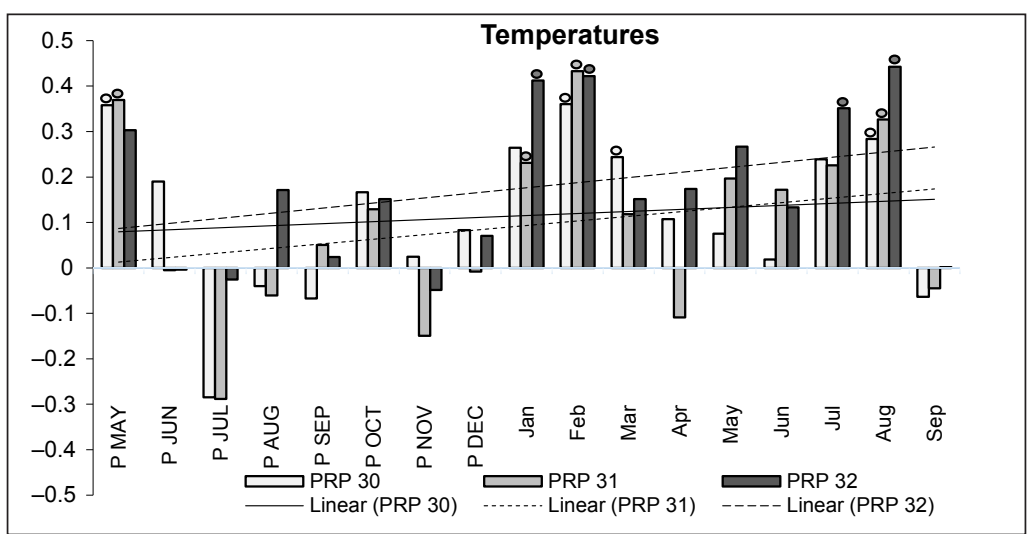

Fig. 4. The values of correlation coefficients of the regional residual index tree-ring chronology of European beech with the monthly temperatures from May of the previous year (P) to September of the current year for the period of 1976-2017 for. Values are statistically significant $(\alpha=0.05)$ and marked with round symbol and linear excel function is calculated for each PRP.

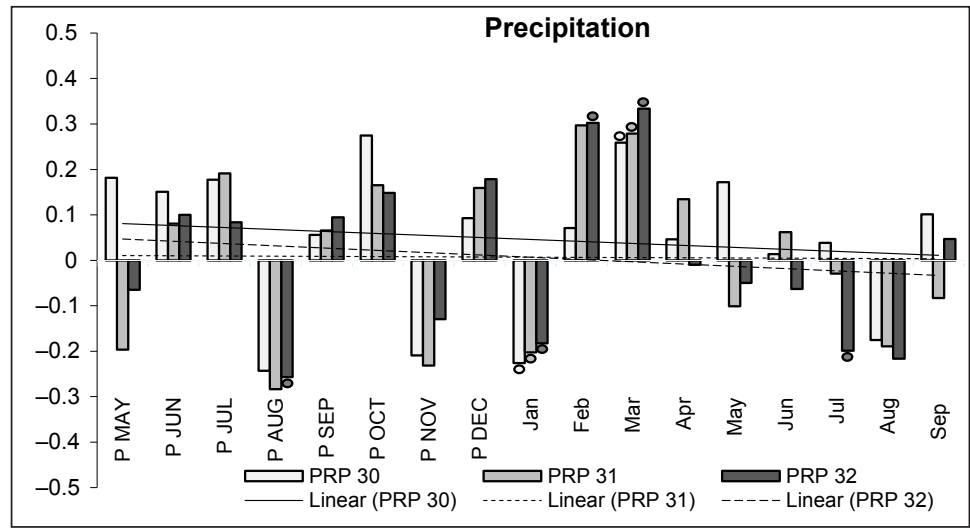

Fig. 5. The values of correlation coefficients of the regional residual index tree-ring chronology of European beech with the monthly precipitation from May of the previous year (P) to September of the current year for the period of 1976-2017. Values are statistically significant $(\alpha=0.05)$ and marked with round symbol and linear excel function is calculated for each PRP.

when the negative correlation was significant only in PRP $32(r=-0.26)$. January of the current year is another significant month, when the negative relationship in the stands on all PRPs was significantly demonstrated $(\mathrm{r}=$ $0.18-0.23)$. Positive correlation was found in March of the current year in stands on all PRPs $(r=0.28-0.33)$ and in February of the current year in the stand on PRP $32(\mathrm{r}=0.30)$. Another significant negative correlation was found in July of the current year $(r=0.20)$. Overall, the growing season shows an increasing negative influence of precipitation on radial growth of European beech (linear curve of all the plots; Fig. 5).

The main factor influencing the diameter increment of European beech in the study area according to regression quadratic model was the temperature (Fig. 6). Annual average temperature had significantly higher effect on radial growth compared to an annual sum of precipitation. Diameter increment only slightly increased with increasing precipitation, while optimal growth was observed in the range of annual air temperature from 5.5 to $6.5^{\circ} \mathrm{C}$.

\subsection{Interactions between radial growth and climate}

In terms of relationships between climate and radial growth presenting by PCA, the first ordination axis explains $32.7 \%$ of data variability, the first two axes together explain $50.0 \%$ and the first four axes $72.2 \%$ (Fig. 7 ). The $x$-axis illustrates the radial growth of beech with temperature parameters and the secondy-axis represents the prevailing precipitation amount. Ring width index was positively correlated with temperature in January to March, out of the growing season and in the growing season of the current year, while temperature in the previous year had low effect on diameter increment. In terms of precipitation, the highest positive correlation of radial growth with precipitation was observed from January to March and out of the growing season of the current year, but these precipitations had small explanatory variable in the ordination diagram. Overall, the effect of temperature on increment was more significant than that of precipitation. Comparing similarity of growth on particular PRPs, diameter increment of beech on PRP 30 


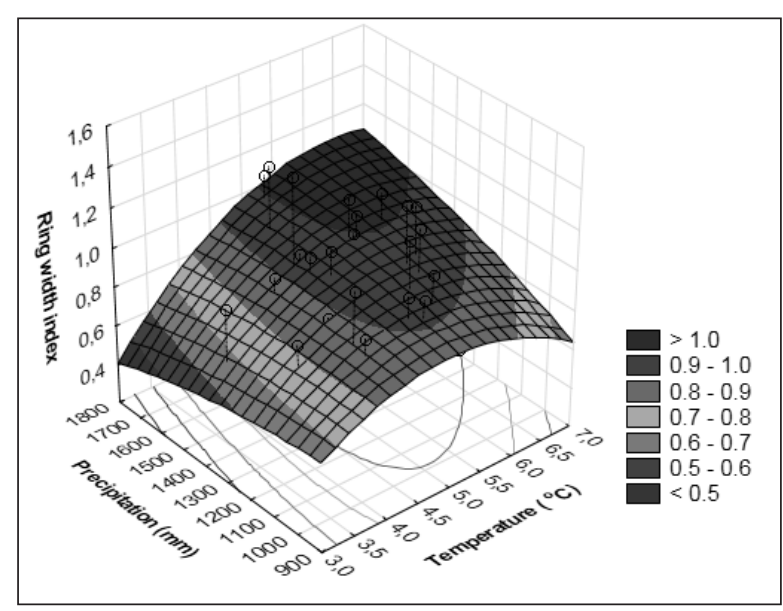

Fig. 6. Response of mean ring width index of European beech to annual sum of precipitation and annual mean temperature for all stands (regression quadratic model, years 1976-2017).

and 31 was very close to each other compared to PRP 32. Species diversity diagram showed that years 2007, 2014, 2015 and 2016 brought the highest values.

\section{Discussion}

A standard dendrochronological analysis suggests that all studied PRPs showed increments of 0.4 to $1.4 \mathrm{RWI}$, which is close to the results obtained from the nearby Orlické hory Mountains, where the index reached similar values 0.4 - 1.6 RWI (Králíček et al. 2017). Foreign studies also show a similar range of values. For example, in southern Sweden, RWI ranges from 0.4 to 1.6 (Bolte et al. 2010).

The development of studied stands was affected by intensive thinning interventions in 1953 (on PRP 31 and 32) and 1954 (on PRP 30), in response to severe frost damage of the stands (beech crown breakage) at the end of winter 1952-1953. The ring series on studied PRPs also show a significant decrease in radial growth during 1975-1989, caused by effect of air-pollution load. Between 1980-1986 average $\mathrm{SO}_{2}$ deposition from the EPO II thermal power plant in Pořičí reached to $59 \mathrm{\mu g} \mathrm{m}^{-3}$, respectively seventeen times higher concertation than nowadays (Samec \& Vránová 2005; Tesař et al. 2011). Air pollution impact on radial growth is well documented in Norway spruce in the Krkonoše Mountains and the whole Sudeten system (Kroupová 2002; Rydval \&Wilson 2012; Vacek et al. 2013; Koláŕ et al. 2015), less in European beech (Vacek \& Hejcman 2012; Králíček et al. 2017). In early spring 1981 , beech crowns were heavily damaged by ice-load and, consequently, the assimilation apparatus of the trees suffered from frost. The air-pollution calamity in 1984 was followed by strong infestation with beech scale (Cryptococcus fagi) and beech-leaf gall midge (Mikiola fagi) (Vacek 1988). Furthermore, lower temperatures during the winter period in 1996 combined with the reverberating pollution load led to beech scale

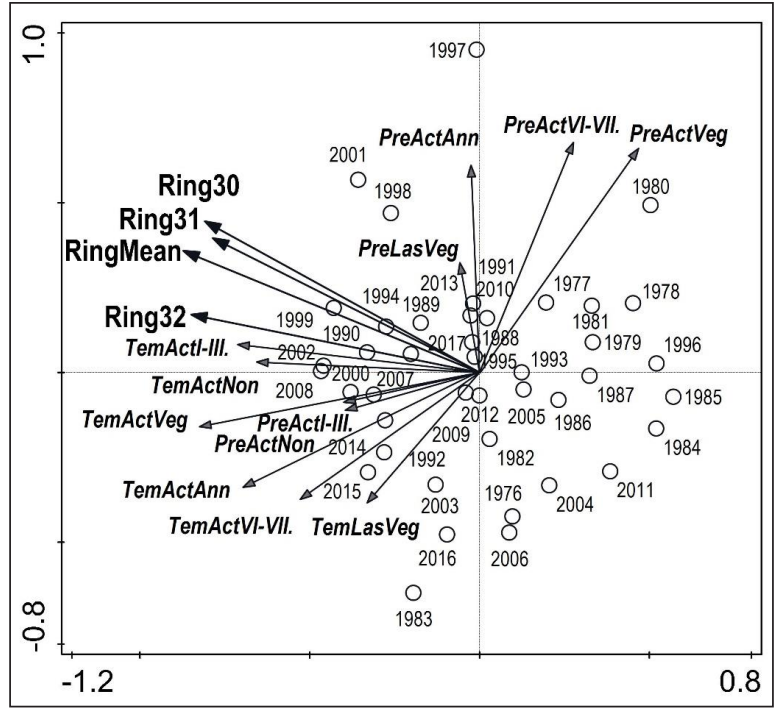

Fig. 7. Ordination diagram of PCA showing relationships between climate data (Tem - mean temperature, Pre - sum of precipitation, Act - current year, Las - previous year, Veg growing season, NonVeg - out of growing season, I-III, VIVII - months) and radial growth (Ring - tree-ring width index) of beech forest stands (PRP 30, 31, 32 and Mean); codes O indicate years 1976-2017.

outbreak, recorded in other mountain regions of the Czech Republic as well (Králíček et al. 2017). A similar situation occurred in Europe in 1976 when beech scale along with extreme drought caused considerable damage and decreased radial growth of European beech (Wainhouse et al.1988). Negative impact of beech scale on beech growth was also recorded in America (Gavin \& Peart 1993; Kasson \& Livingston 2009, 2012). To a lesser extent, ice-load induced crown damage repeated in winter 2004-2005. Above mentioned types of damage on many PRPs in the Krkonoše Mountains was reported by Vacek et al. (2007). Assimilation apparatus was severely damaged at the beginning of the vegetation period in 2011 and, less severely, in 2016. In respect to the economic function of studied beech stands until 1963, their development on all PRPs was different, which has also been confirmed (Kooijman et al. 2000).

A spectral dendrochronology analysis shows, in all PRP stands, $10-18$ years' cycles occurring in the largest frequency spectrum. Short, mostly 2-year cycles are usually rationalized by fructification and seed-year cyclicity (Övergaard 2010; Nussbaumer et al. 2018) or local climate particularities associated with fructification of European beech (Drobyshev et al. 2010) or other events such as spring late frosts (Vacek \& Hejcman 2012). More significant cycles occur in $10-18$ years' periods, mainly due to repeated extensive harvesting or climatic extremes in given periods (Mausolf et al. 2018). However, detailed studies on cyclical growth of European beech in the Sudeten system are yet to be carried out.

The relation of European beech radial growth to monthly sum of precipitation was similar in all stands 
on the PRPs. Negative correlations were recorded in August of the previous year and in January of the current year. Positive correlations were observed in February and March of the current year. Statistically significant negative correlations were also documented in July and August of the current year. The results are comparable with Králíček et al. (2017), who present similar positive correlations until March and negative impact of precipitation on radial growth in July. In Sweden, European beech does not suffer from the lack of precipitation as much as in our country, but a minor positive effect of precipitation in early spring is detectable (Drobyshev et al. 2010).

The relation of radial growth of European beech to average monthly temperatures suggest the prevailing positive influence of temperatures, except in July of previous year. In rare cases, however, extreme frosts negatively affected radial growth in late spring (in 1996, 2011 and 2016). Similar events are reported by Vacek \& Hejcman (2012) from the western parts of Krkonoše. In our study, the most significant month influencing radial growth was August in current year, similarly such as in beech forests in Balkan (Tegel et al. 2014). A comparison of our results and the study of European beech from the Orlické hory Mountains (Králíček et al. 2017) shows that our results from the Krkonoše Mts. differ in these correlations by two months earlier. Also, the results of a study carried out in Turkey show a similar trend of a shift in Fagus orientalis (Köse \& Güner 2012). In contrast to the Swedish growth conditions (Drobyshev et al. 2010), the correlation we have found is significantly positive.

The main climatic factor affecting the growth of beech trees in the studied montane localities is the positive effect of temperature. This was also observed by Vacek \& Hejcman (2012) in beech stands at higher altitudes of the Krkonoše Mountains. On the contrary, at lower altitudes of the Czech Republic high temperatures were a limiting factor of growth, especially in the growing season (Remeš et al. 2015). The altitude significantly supports the influence of climatic factors on radial growth; the positive effect of temperature on radial growth increases with the altitude, especially in June and July (Meyer \& Bräker 2001; Andreassen et al. 2006; Hauck et al. 2012). A similar situation is reported from Germany and Italy, where the temperature had significant positive influence in May in montane areas (1560 m a.s.l.), while in the lowlands ( $420-450 \mathrm{~m}$ a.s.l.) the temperature in June had a negative impact on the radial growth of the beech (Skomarkova et al. 2006). In contrast, OpałaOwczarek et al. (2018) documented that the temperature from April to June is decisive for the radial growth in the mountainous parts of the Sudetes. The diameter increment is a slightly less influenced by precipitation, as described by regression quadratic model and PCA or foreign references (Ježík et al. 2016; Rohner et al. 2016). It can be assumed that the global warming and lack of pre- cipitation will bring growth decline at lower altitudes and growth increase at higher altitudes in the centre of the beech distribution range (Penuelas et al. 2007; Kramer et al. 2010; Dulamsuren et al. 2017; Ruosteenoja et al. 2018). The trend is confirmed by gradual expansion of natural regeneration of beech in montane areas in recent years (Vacek et al. 2015c; Janík et al. 2016). Similarly, global climate change may lead to rapid decline in the growth of range-edge populations, consequent retreat of the beech distribution in southern Europe and conversely it spread to the north (Sykes \& Prentice 1996; Jump et al. 2006). On the base of modern species distribution models, the ecological consequences of the range contractions would lead to serious nature conservation and forest management in future (Dyderski et al. 2018).

\section{Conclusion}

Growth and development of beech stands in the Krkonoše National Park is influenced by several abiotic (late frosts, droughts), biotic (beech scale, beech-leaf gall midge) and anthropogenic factors (extensive harvesting, air pollution load). The climatically significant years show that radial growth of the stands on the PRPs responded differently, but low temperatures during the growing season and lack of precipitation at the beginning of the year were the most important limiting factors. The overall effect of the average temperature on the beech diameter increase was significantly higher compared to precipitation. As regards the radial growth period, 2-year cycles were most often followed by cycles ranging from 10 to 18 years. Dendrochronological analyses of close-to-nature beech stands show us possible trends of their development in the ongoing global climate change, as European beech is considered to be one of the most important tree species in the Czech Republic.

\section{Acknowledgement}

This study was supported by the Czech University of Life Sciences Prague, Faculty of Forestry and Wood Sciences (No. IGA B03/18).

\section{References}

Andreassen, K., Solberg, S., Tveito, O. E., Lystad, S. L., 2006: Regional differences in climatic responses of Norway spruce (Picea abies L. Karst) growth in Norway. Forest Ecology and Management, 222:211221.

Biondi, F., Waikul, K., 2004: DENDROCLIM2002AC+ + program for statistical calibration of climate signals in tree-ring chronologies. Computers \& Geosciences, 30:303-311. 
Bolte, A., Hilbrig, L., Grundmann, B., Kampf, F., Brunet, J., Roloff, A., 2010: Climate change impacts on stand structure and competitive interactions in a southern Swedish spruce-beech forest. European Journal of Forest Research, 129:261-276.

Bošela, M., Štefančík, I., Petráš, R., Vacek, S., 2016:The effects of climate warming on the growth of European beech forests depend critically on thinning strategy and site productivity. Agricultural and Forest Meteorology, 222:21-31.

Brázdil, R., Trnka, M., Miksovský, J., Tolasz, R., Dobrovolný, P., Reznícková, L. et al., 2017: Drought events in the Czech Republic: past, present, future. In: 19th EGU General Assembly, proceedings from the conference held 23-28 April, 2017 in Vienna, Austria, $19285 \mathrm{p}$.

Brázdil, R., Stucki, P., Szabó, P., Řezníčková, L., Dolák, L., Dobrovolný, P. et al., 2018: Windstorms and forest disturbances in the Czech Lands: 1801-2015. Agricultural and Forest Meteorology, 250:47-63.

Bridgman, H. A., Davies, T. D., Jickells, T., Hunova, I., Tovey, K., Bridges, K. et al., 2002: Air pollution in the Krusne Hory region, Czech Republic during the 1990s. Atmospheric Environment, 36:3375-3389.

Bunn, A., Korpela, M., 2018a: Time Series Analysis in dplR, 14 p.

Bunn, A., Korpela, M., 2018b: Chronology Building in dplR, 13 p.

Bytnerowicz, A., Omasa, K., Paoletti, E., 2007: Integrated effects of air pollution and climate change on forests: A northern hemisphere perspective. Environmental Pollution, 147:438-445.

Cavin, L., Jump, A. S., 2017: Highest drought sensitivity and lowest resistance to growth suppression are found in the range core of the tree Fagus sylvatica L. not the equatorial range edge. Global Change Biology, 23:362-379.

Christensen, M., Hahn, K., Mountford, E. P., Ódor, P., Standovár, T., Rozenberger, D. J. et al., 2005: Dead wood in European beech (Fagus sylvatica) forest reserves. Forest Ecology and Management, 210:267-282.

Cicák, A., Mihál, I., Tsakov, H., Petkov, P., 2006: Actual status of the beech bark necrotic disease in North Western Bulgaria. Journal of Forest Science, 52:226232.

Dittmar, C., Zech, W., Elling, W., 2003: Growth variations of Common beech (Fagus sylvatica L.) under different climatic and environmental conditions in Europe-a dendroecological study. Forest Ecology and Management, 173:63-78.

Drobyshev, I., Övergaard, R., Saygin, I., Niklasson, M., Hickler, T., Karlsson, M. et al., 2010: Masting behaviour and dendrochronology of European beech (Fagus sylvatica L.) in southern Sweden. Forest Ecology and Management, 259:2160-2171.
Dulamsuren, C., Hauck, M., Kopp, G., Ruff, M., Leuschner, C., 2017: European beech responds to climate change with growth decline at lower, and growth increase at higher elevations in the center of its distribution range (SW Germany). Trees - Structure and Function, 31:673-686.

Dyderski, M. K., Paź, S., Frelich, L. E., Jagodziński, A. M., 2018: How much does climate change threaten European forest tree species distributions? Global Change Biology, 24:1150-1163.

Filippo, A. D. I., Biondi, F., Maugeri, M., 2012: Bioclimate and growth history affect beech lifespan in the Italian Alps and Apennines. Global Change Biology, 18:960-972.

Gavin, D. G., Peart, D. R., 1993: Effects of beech bark disease on the growth of American beech (Fagus grandifolia). Canadian Journal of Forest Research, 23:1566-1575.

Geßler, A., Keitel, C., Matyssek, R., Seiler, W., Rennenberg, H., 2007: Potential risks for European beech (Fagus sylvatica L .) in a changing climate Potential risks for European beech (Fagus sylvatica L.). Trees, 21:1-11.

Granier, A., Reichstein, M., Bréda, N., Janssens, I. A., Falge, E., Ciais, P., 2007: Evidence for soil water control on carbon and water dynamics in European forests during the extremely dry year: 2003. Agricultural and Forest Meteorology, 143:123-145.

Hartl-Meier, C., Zang, C., Büntgen, U., Esper, J., Rothe, A., Göttlein, A. et al., 2018: Uniform climate sensitivity in tree-ring stable isotopes across species and sites in a mid-latitude temperate forest. Tree Physiology, 35:4-15.

Hauck, M., Zimmermann, J., Jacob, M., Dulamsuren, C., Bade, C., Ahrends, B. et al., 2012: Rapid recovery of stem increment in Norway spruce at reduced $\mathrm{SO}_{2}$ levels in the Harz Mountains, Germany. Environmental Pollution, 164:132-141.

Holuša, J., Lubojacký, J., Čurn, V., Tonka, T., Lukášová, K., Horák, J., 2018: Combined effects of drought stress and Armillaria infection on tree mortality in Norway spruce plantations. Forest Ecology and Management, 427:434-455.

Hůnová, I., Schreiberová, M., 2012: Ambient ozone phytotoxic potential over the $\mathrm{Czech}$ forests as assessed by AOT40. iForest-Biogeosciences and Forestry, 5:153.

IFER 2017: Field-Map Software \& Hardware Catalogue - www.fieldmap.com. IFER - Monitoring and Mapping Solutions, Ltd., Jílové u Prahy, 51 p.

Janík, D., Král, K., Adam, D., Hort, L., Samonil, P., Unar, P. et al., 2016: Tree spatial patterns of Fagus sylvatica expansion over 37years. Forest Ecology and Management, 375:134-145.

Ježík, M., Blaženec, M., Kučera, J., Střelcová, K., Ditmarová, L., 2016: The response of intra-annual stem circumference increase of young European beech provenances to 2012-2014 weather variability. IForest, 9:960-969. 
Jump, A. S., Hunt, J. M., Penuelas, J., 2006: Rapid climate change-related growth decline at the southern range edge of Fagus sylvatica. Global Change Biology, 12:2163-2174.

Kasson, M.T., Livingston, W. H., 2009: Spatial distribution of Neonectria species associated with beech bark disease in northern Maine. Mycologia, 101:190-195.

Kasson, M. T., Livingston, W. H., 2012: Relationships among beech bark disease, climate, radial growth response and mortality of American beech in northern Maine, USA. Forest Pathology, 42:199-212.

Kolář, T., Čermák, P., Oulehle, F., Trnka, M., Štěpánek, P., Cudlín, P. et al., 2015: Pollution control enhanced spruce growth in the "Black Triangle" near the Czech-Polish border. Science of the Total Environment, 538:703-711.

Kooijman, A. M., Emmer, I. M., Fanta, J., Sevink, J., 2000: Natural regeneration potential of the degraded Krkonoše forests. Land Degradation and Development, 11:459-473.

Köse, N., Güner, H. T., 2012: The effect of temperature and precipitation on the intra-annual radial growth of Fagus orientalis Lipsky in Artvin, Turkey. Turkish Journal of Agriculture and Forestry, 36:501-509.

Král, J., Vacek, S., Vacek, Z., Putalová, T., Bulušek, D., Štefančík, I., 2015: Structure, development and health status of spruce forests affected by air pollution in the western Krkonoše Mts. in 1979-2014. Lesnícky časopis - Forestry Journal, 61:175-187.

Králíček, I., Vacek, Z., Vacek, S., Remeš, J., Bulušek, D., Král, J. et al., 2017: Dynamics and structure of mountain autochthonous spruce-beech forests: Impact of hilltop phenomenon, air pollutants and climate. Dendrobiology, 77:119-137.

Kramer, K., Degen, B., Buschbom, J., Hickler, T., Thuiller, W., Sykes, M. T. et al., 2010: Modelling exploration of the future of European beech (Fagus sylvatica L.) under climate change-range, abundance, genetic diversity and adaptive response. Forest Ecology and Management, 259:2213-2222.

Kroupová, M., 2002: Dendroecological study of spruce growth in regions under long-term air pollution load. Journal of Forest Science, 48:536-548.

Lindner, M., Maroschek, M., Netherer, S., Kremer, A., Barbati, A., Garcia-Gonzalo, J. et al., 2010: Climate change impacts, adaptive capacity, and vulnerability of European forest ecosystems. Forest Ecology and Management, 259:698-709.

Ling, K. A., Power, S. A., Ashmore, M. R., 1993: A survey of the health of Fagus sylvatica in southern Britain. Journal of Applied Ecology, 30:295-306.

Lokvenc, T., 1978: Toulky krkonošskou minulostí. Kruh, Hradec Králové, 267 p.

Matějka, K., Vacek, S., Podrázský, V., 2010: Development of forest soils in the Giant Mts. in the period 1980-2009. Journal of Forest Science, 56:485-504.
Materna, J., 1989: Air pollution and forestry in Czechoslovakia. Environmental Monitoring and Assessment, 12:227-239.

Mausolf, K., Wilm, P., Härdtle, W., Jansen, K., Schuldt, B., Sturm, K. et al., 2018: Higher drought sensitivity of radial growth of European beech in managed than in unmanaged forests. Science of the Total Environment, 642:1201-1208.

Meyer, F. D., Bräker, O. U., 2001: Climate response in dominant and suppressed spruce trees, Picea abies (L.) Karst., on a subalpine and lower montane site in Switzerland. Ecoscience, 8:105-114.

Mihál, I., Cicák, A., Tsakov, H., 2014: Selected biotic vectors transmitting beech bark necrotic disease in Central and South-Eastern Europe. Folia Oecologica, 41:62-74.

Ministry of Agriculture, 2017: Zpráva o stavu lesa a lesního hospodářství České republiky v roce 2016. Praha, $132 \mathrm{p}$.

Motta, E., Annesi, T., Pane, A., Cooke, D. E. L., Cacciola, S. O., 2003: A new Phytophthora sp. causing a basal canker on beech in Italy. Plant Disease, 87:10051005.

Nožička, J., 1961: Vývoj krkonošských lesů na Vrchlabsku a Maršovsku. Práce VÜLHM, 18:161-228.

Nussbaumer, A., Waldner, P., Apuhtin, V., Aytar, F., Benham, S., Bussotti, F. et al., 2018: Impact of weather cues and resource dynamics on mast occurrence in the main forest tree species in Europe. Forest Ecology and Management, 429:336-350.

Opała-Owczarek, M., Błaś, M., Owczarek, P., Sobik, M., Godek, M., 2019: A dendroclimatological study of east- and west-facing slopes in mountainousareas subjected to strong air pollution (the Sudetes, Central Europe), Physical Geography, 40:186-208.

Övergaard, R., 2010: Seed Production and Natural Regeneration of Beech (Fagus sylvatica L.) in Southern Sweden. Swedish University of Agricultural Sciences, $74 \mathrm{p}$.

Peters, R., 1997: Beech Forests. Kluwer Academic Publishers, Dordrecht, The Netherlands, p. 39-40.

Paoletti, E., Schaub, M., Matyssek, R., Wieser, G., Augustaitis, A., Bastrup-Birk, A. M. et al., 2010: Advances of air pollution science: from forest decline to multiple-stress effects on forest ecosystem services. Environmental Pollution, 158:1986-1989.

Penuelas, J., Ogaya, R., Boada, M., S. Jump, A., 2007: Migration, invasion and decline: changes in recruitment and forest structure in a warming-linked shift of European beech forest in Catalonia (NE Spain). Ecography, 30:829-837.

Power, S. A., Ashmore, M. R., 1996: Nutrient relations and root mycorrhizal status of healthy and declining beech (Fagus sylvatica L.) in southern Britain. Water, Air, and Soil Pollution, 86:317-333. 
Remeš, J., Bílek, L., Novák, J., Vacek, Z., Vacek, S., Putalová, T., Koubek, L., 2015: Diameter increment of beech in relation to social position of trees, climate characteristics and thinning intensity. Journal of Forest Science, 61:456-464.

Rohner, B., Weber, P., Thürig, E., 2016: Bridging tree rings and forest inventories: How climate effects on spruce and beech growth aggregate over time. Forest Ecology and Management, 360:159-169.

Ruosteenoja, K., Markkanen, T., Venäläinen, A., Räisänen, P., Peltola, H. ,2018: Seasonal soilmoisture and drought occurrence in Europe in CMIP5 projections for the 21 st century. Climate Dynamics, 50:1177-1192.

Rydval, M., Wilson, R., 2012: The impact of industrial $\mathrm{SO}_{2}$ pollution on north Bohemia conifers. Water, Air, \& Soil Pollution, 223:5727-5744.

Samec, P., Vránová, V., 2005: Bioindication of soil sorption properties in the substitute tree stands at submontane conditions. In: Šimková, P.: MendelNet 2005, Contemporary state and development trends of forest in cultural landscape. Brno, Mendelova univerzita v Brně, p. 113-119.

Schütz, J. P., 2001: Der Plenterwald. Parey Buch-verlag, Berlin, 207 p.

Skomarkova, M. V., Vaganov, E. A., Mund, M., Knohl, A., Linke, P., Boerner, A. et al., 2006: Inter-annual and seasonal variability of radial growth, wood density and carbon isotope ratios in tree rings of beech (Fagus sylvatica) growing in Germany and Italy. Trees, 20:571-586.

Slanař, J., Vacek, Z., Vacek, S., Bulušek, D., Cukor, J., Štefančík, I. et al., 2017: Long-term transformation of submontane spruce-beech forests in the Jizerské hory Mts.: Dynamics of natural regeneration. Central European Forestry Journal, 63:212-224.

Sykes, M. T., Prentice, I. C., 1996: Climate change, tree species distributions and forest dynamics: a case study in the mixed conifer/northern hardwoods zone of northern Europe. Climatic Change, 34:161-177.

Špulák, O., Souček, J., 2010: The Sibyla model and development of beech forests affected by air pollution. Central European Journal of Biology, 5:317-383.

Team R Core, 2018: A language and environment for statistical computing. R Foundation for Statistical Computing. Vienna, Austria.

Tegel, W., Seim, A., Hakelberg, D., Hoffmann, S., Panev, M., Westphal, T., Büntgen, U., 2014:A recent growth increase of European beech (Fagus sylvatica L.) at its Mediterranean distribution limit contradicts drought stress. European Journal of Forest Research, 133:6171.

Tesař, V., Balcar, V., Lochman, V., Nehyba, J., 2011. Přestavba lesa zasaženého imisemi na Trutnovsku. Brno, Mendelova univerzita v Brně, 177 p.

Tolazs, R., 2007:Atlas podnebí Česka. Praha alomouc, $256 \mathrm{p}$.
Trnka, M., Brázdil, R., Možný, M., Štěpánek, P., Dobrovolný, P., Zahradníček, P. et al., 2015: Soil moisture trends in the Czech Republic between 1961 and 2012. International Journal of Climatology, 35:3733-3747.

Vacek, S., 1988: Dynamics of the defoliation of beech forest stands under the influence of air pollution. In: 3. IUFRO Buchensymposium. Zvolen, 3. 6. - 6. 6 . 1988. Zvolen, VŠLD, p. 377-388.

Vacek, S., Matějka, K., Simon, J., Malík, V., Schwarz, O., Podrázský, V. et al., 2007:Zdravotní stav a dynamika lesních ekosystémů Krkonoš pod stresem vyvolaným znečištěním ovzduší. Folia forestalia Bohemica, Kostelec nad Černými lesy, Lesnická práce, 4:216 p.

Vacek, S., Nosková, I., Bílek, L., Vacek, Z., Schwarz, O., 2010: Regeneration of forest stands on permanent research plots in the Krkonoše Mts. Journal of Forest Science, 56:541-554.

Vacek, S., Hejcman, M., 2012: Natural layering, foliation, fertility and plant species composition of a Fagus sylvatica stand above the alpine timberline in the Giant (Krkonoše) Mts., Czech Republic. European Journal of Forest Research, 131:799-810.

Vacek, S., Bílek, L., Schwarz, O., Hejcmanová, P., Mikeska, M., 2013: Effect of Air Pollution on the Health Status of Spruce Stands Effect of Air Pollution on the Health Status of Spruce Stands. Mountain Research and Development, 33:40-50.

Vacek, S., Hůnová, I., Vacek, Z., Hejcmanová, P., Podrázský, V., Král, J., 2015a: Effects of air pollution and climatic factors on Norway spruce forests in the Orlické hory Mts. (Czech Republic) 1979-2014. European Journal of Forest Research, 134:11271142.

Vacek, S., Černý, T., Vacek, Z., Podrázský, V., Mikeska, M., Králíček, I., 2017: Long-term changes in vegetation and site conditions in beech and spruce forests of lower mountain ranges of Central Europe. Forest Ecology and Management, 398:75-90.

Vacek, Z., Vacek, S., Bílek, L., Remeš, J., Štefančík, I., 2015b: Changes in horizontal structure of natural beech forests on an altitudinal gradient in the Sudetes. Dendrobiology, 73:33-45.

Vacek, Z., Vacek, S., Podrázský, V., Bílek, L., Štefančík, I., Moser, W. K. et al., 2015c: Effect of tree layer and microsite on the variability of natural regeneration in autochthonous beech forests. Polish Journal of Ecology, 63:233-246.

Viewegh, J., Kusbach, A., Mikeska, M., 2003: Czech forest ecosystem classification. Journal of Forest Science, 49:85-93.

Wainhouse, D., Gate, I. M., Lonsdale, D., 1988: Beech Resistance to the Beech Scale:A Variety of Defenses. In: Mattson, V. J., Levieux, J., Bernard-Dagan, C. (eds.): Mechanisms of Woody Plant Defenses against Insects. Springer, New York, NY, p. 277-293.

Urban, J., 2000: Beech gall midge (Mikiola fagi Htg.) and its natural enemies. Journal of Forest Science, 46:543-568. 
Zang, C., Hartl-Meier, C., Dittmar, C., Rothe, A., Menzel, A., 2014: Patterns of drought tolerance in major European temperate forest trees: Climatic drivers and levels of variability. Global Change Biology, 20:3767-3779.
Zang, C., Rothe, A., Weis, W., Pretzsch, H., 2011: Zur baumarteneignung bei klimawandel: Ableitung der trockenstress- anfälligkeit wichtiger waldbaumarten aus jahrringbreiten. Allgemeine Forst- und Jagdzeitung, 182:98-112. 